\title{
Exploring the effect of employability and job characteristics on contextual performance: Mediat- ing by organizational commitment
}

\author{
Rita Aryani ${ }^{a *}$ and Widodo Widodo ${ }^{b}$
}

${ }^{a}$ Pancasakti College of Teachers Training and Education, Bekasi, Indonesia

${ }^{b}$ Faculty of Education and Social Sciences of Indraprasta University, Jakarta, Indonesia

\section{CHRON I C L E}

\section{Article history:}

Received: October 16, 2019

Received in revised format:

January 302020

Accepted: February 6, 2020

Available online:

February 6, 2020

Keywords:

Employability

Job characteristics

Organizational commitment

Contextual performance

\begin{abstract}
A B S T R A C T
The objective of this research was to explore the direct effect of employability and job characteristics on contextual performance of vocational high school principals mediating by organizational commitment. This research used some quantitative approach with survey method. The samples of this research included 216 principals selected randomly. The data were obtained by spreading questionnaires and analyzed with path analysis by supporting descriptive statistics. The results confirm that employability, job characteristics, and organizational commitment had significant direct effects on contextual performance; employability and job characteristics had significant direct effects on organizational commitment; employability and job characteristics had significant indirect effects on contextual performance mediating by organizational commitment. Therefore, a fit research model found about the effect of employability and job characteristics on contextual performance mediating by organizational commitment. This model can be used as a reference by researchers and practitioners in developing models of contextual performance in the future.
\end{abstract}

\section{Introduction}

Indonesia's Human Development Index (HDI) has not shown significant progress. Indonesia's HDI in 2019 is 111 out of 189 countries in the world. This condition contrasts with the demands of globalization. When international globalization requires superior and competitive quality human resources (HR), Indonesia's HDI tends to be stagnant. That is, the quality of Indonesian human resources did not progress at all so that they were not ready to compete, even with fellow HR from ASEAN countries. This condition shows that in the perspective of national education in Indonesia, especially graduates of vocational high schools are clearly inadequate. The problem requires strengthening the performance of vocational high school principals, because the principal has the central role and the highest authority in the school.

\subsection{Contextual Performance}

According to Aguinis (2013:88), "performance is about behavior or what employees do, not about what employees produce or the outcomes of their work." This view is supported by Ivancevich, Konopaske and Matteson (2014:172) who state that "performance is a set of employee work related behaviors designed to accomplish organizational goals." Likewise, Byars, Rue and Ibtrahim (2016: 216) say "performance as degree of accomplishment of the task that make up an employee's job. It reflects how well an employee is fulfilling the requirements of a job." Therefore, performance can be viewed from a perspective on contextual performance, which includes those behaviors that contribute to the organization's effectiveness by providing a good environment in which task performance can occur. Contextual performance includes behaviors such as the following: (1) persisting with enthusiasm and exerting extra effort as necessary to complete one's own task activities successfully; * Corresponding author.

E-mail address: ritaar1757@gmail.com (R. Aryania) 
(2) volunteering to carry out task activities that are not formally part of the job; (3) helping and cooperating with others; (4) following organizational rules and procedures; and (5) endorsing, supporting, and defending organizational objectives (Aguinis, 2013).

\subsection{Employability}

Contextual performance, among others, is influenced by employability. The results of research by Abas-Mastura, Imam and Osman (2013), Philippaers et al. (2016), and Pinto and Ramalheira (2017) show employability has a direct effect on contextual performance. Employability is referred to as individuals' capabilities to maintain, nurture and develop competencies and qualifications which can enhance their sustainable labor market participation and their career potential (van der Heijde \& van der Heijden, 2006; Berntson \& Marklund, 2007). In other words, employability is an individual's work-centered adaptability that enhances his or her abilities to find and use job and career opportunities within or outside the current workplace (Forrier $\&$ Sels, 2003), or a form of work specific active adaptability that enables workers to identify and realize career opportunities (Fugate, Kinicki, \& Ashforth, 2004). Employability also is often viewed as a 'win-win' for all labor market parties. It is argued that it makes workers better equipped to take on other types of jobs inside or outside their current employment if necessary, meanwhile enabling organizations to meet fluctuating and unpredictable market demands (Nauta, van Vianen, van der Heijden, van Dam, \& Willemsen, 2009). Feelings of employment security also improves when employers provide outplacement assistance as part of the severance package offered to laid-off workers (Jackson, Schuler, \& Werner, 2009). Van der Heijde and van der Heijden (2006) state that conceptually in employability; there are five dimensions that describe inherently paradoxical. This is interpreted as a dimension that reflects in maintaining and increasing employability means simultaneous, persistent and often conflicting investment in workers. The five dimensions are: (1) domain-specific occupational expertise and more general competences in order to enhance their; (2) proactive; (3) reactive adaptability to labor market and organizational changes, meanwhile maintaining their; (4) occupational sense (commitment to organizational and team goals); and (5) balance between organizational and personal interests (including health, vitality, and work-life balance). Thus, it can be hypothesized:

$\mathrm{H}_{1}$ : Employability has a direct effect on contextual performance.

\subsection{Job characteristics}

Contextual performance is also influenced by job characteristics. Several studies report that job characteristics has a direct effect on contextual performance, for example: Johari, Yean, Yahya and Adnan (2015), Brooks and Califf (2016), Rijanti, Priyono and Nugroho (2017), Amahwa and Mukanzi (2018), Abasalizadeh and Dadgarinezhad (2018); Sugianto, Muhyi and Purnomo (2018), and Peiroa et al. (2020). Bernardin and Russell (2013:130) also argue that job characteristics of the model emphasizes enhancing the intrinsic aspect of an employee's work to increase performance. According to Snell and Bohlander (2010: 164), "job characteristics model is a job design theory that purports that three psychological states (experiencing meaningfulness of the work performed, responsibility for work outcomes, and knowledge of the results of the work performed) of a job holder result in improved work performance, internal motivation, and lower absenteeism and turnover." Hackman and Oldam as quote by Noe et al. (2015) identified five dimensions of job characteristics, namely: (1) skill variety is the extent to which the job requires a variety of skills to carry out the tasks, (2) task identity is the degree to which a job requires completing a "whole" piece of work from beginning to end, (3) autonomy is the degree to which the job allows an individual to make decisions about the way the work will be carried out, (4) feedback is the extent to which a person receives clear information about performance effectiveness from the work itself, and (5) task significance is the extent to which the job has an important impact on the holes of other people. Thus, it can be hypothesized:

$\mathrm{H}_{2}$ : Job characteristics has a direct effect on contextual performance.

\subsection{Organizational commitment}

In Addition, contextual performance is also influenced by organizational commitment. Several studies have shown that organizational commitment has a direct effect on performance, for example: Harwiki (2016), Anggapradja and Wijaya (2017), Renyut, Modding, Bima, and Sukmawati (2017), Destari, Lumbanraja and Absah (2018), Khunsoonthornkit and Panjakajornsak (2018), Fajrin, Saragih and Indratjahjo (2018), Lin and Shiqian (2018), Metin and Asli (2018), Suharto, Suyanto and Hendri (2019). Organizational commitment is "the degree to which an employee identifies with the organization and is willing to put forth effort on its behalf" (Noe, Hollenbeck, Gerhart, \& Wright, 2015:467), or "the attitudinal experience of commitment occurs apart from, or as a consequence of, day-to-day work activity" (Beardwell \& Thompson, 2017:397). Meyer and Allen as quote Beardwell and Thompson (2017) identify three different types of commitment: normative, continuance and affective commitment. Normative or moral commitment occurs where individual feel that they ought to be committed to the organization, regardless of whether or not they actually believe in the organization's values. Continuance commitment is where an individual chooses to remain with an organization as long as they consider that the benefits of doing so outweigh the costs of leaving. With affective commitment, individuals feel an emotional attachment to the organization. Thus, it can be hypothesized:

$\mathrm{H}_{3}$ : Organizational commitment has a direct effect on contextual performance. 
Organizational commitment in addition to influencing contextual performance is also influenced by employability. The results of research carried out by Benson (2006), de Cuyper and de Witte (2011), and Yousaf and Sanders (2012) show that employability affects organizatinonal commitment. Thus, it can be hypothesized:

$\mathrm{H}_{4}$ : Employability has a direct effect on organizational commitment.

Organizational commitment is also influenced by job characteristics. Several studies conducted by Chang and Lee (2006), Ali (2015), Obi-Nwosu, Chiamaka and Tochukwu (2013), and Sabella, El-Far and Eid (2016) have shown that job characteristics influences organizational commitment. Thus, it can be hypothesized:

$\mathrm{H}_{5}$ : Job characteristics has a direct effect on organizational commitment.

\section{Research Methods}

This study used a sample of 216 principals taken by proportionate random sampling from 493 principals of Private Vocational High Schools in DKI Jakarta Province, Indonesia based on the provisions in Krejcie and Morgan Table (1970). Research data collection was carried out using a questionnaire in the form of a Likert scale with five alternative answers: strongly disagree, disagree, neutral, agree and strongly agree. Data analysis was performed using descriptive statistics and path analysis. Data processing was done with SPSS 22 and Lisrel 8.80 software.

\section{Research Result}

The results of the descriptive statistical analysis for the four research variables are presented as followed:

Table 1

Descriptive statistics

\begin{tabular}{|c|c|c|c|c|c|}
\hline & & Employability & Job Characteristics & Organizational Commitment & Contextual Performance \\
\hline \multirow[t]{2}{*}{$\mathrm{N}$} & Valid & 216 & 216 & 216 & 216 \\
\hline & Missing & 0 & 0 & 0 & 0 \\
\hline \multicolumn{2}{|c|}{ Mean } & 134.85 & 109.06 & 111.78 & 113.00 \\
\hline \multicolumn{2}{|c|}{ Median } & 135.00 & 110.00 & 112.00 & 114.00 \\
\hline \multicolumn{2}{|c|}{ Mode } & 139 & 120 & 114 & 126 \\
\hline \multicolumn{2}{|c|}{ Std. Deviation } & 9.501 & 18.111 & 8.875 & 11.749 \\
\hline \multicolumn{2}{|c|}{ Variance } & 90.260 & 328.024 & 78.757 & 138.033 \\
\hline \multicolumn{2}{|c|}{ Range } & 48 & 91 & 40 & 56 \\
\hline \multicolumn{2}{|c|}{ Minimum } & 105 & 57 & 89 & 77 \\
\hline \multicolumn{2}{|c|}{ Maximum } & 153 & 148 & 129 & 133 \\
\hline \multicolumn{2}{|c|}{ Sum } & 29127 & 23558 & 24145 & 24407 \\
\hline
\end{tabular}

As shown in Table 1, the mean values of the four variables from the lowest to the highest in succession are job characteristics (109.06), organizational commitment (111.78), contextual peformance (113.00), and employability (134.85). The results of hypothesis testing with path analysis of the effects of employability, job characteristics, and organizational commitment on contextual performance are summarized as followed:

Table 2

Summary of path coefficients and t value

\begin{tabular}{cccc}
\hline Hyphothesis & Path coefficient & t value & Hyphothesis Testing \\
\hline $\mathrm{H}_{1}$ & $.37^{* *}$ & 5.25 & Accepted \\
$\mathrm{H}_{2}$ & $.22^{* *}$ & 3.65 & Accepted \\
$\mathrm{H}_{3}$ & $.22^{* *}$ & 2.87 & Accepted \\
$\mathrm{H}_{4}$ & $.57^{* *}$ & 11.60 & Accepted \\
$\mathrm{H}_{5}$ & $.32^{* *}$ & 6.56 & Accepted \\
\hline$*=p<01$ & & &
\end{tabular}

The results of the path coefficient and t value can be described as followed:

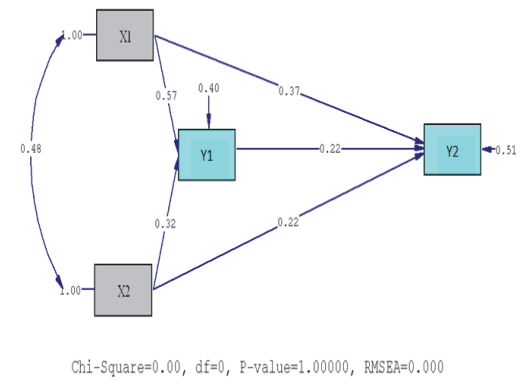

Fig. 1. Path Coeficient

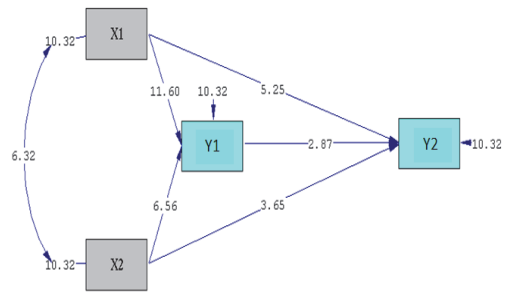

Chi-Square $=0.00, \mathrm{df}=0, \mathrm{P}-\mathrm{valu}=1.00000, \mathrm{R} M \mathrm{SEA}=0.000$

Fig. 2. T Value 
The test results of Table 2 show that all hypotheses were accepted. Employability, job characteristics, and organizational commitment had a significant direct effect on contextual performance. Employability and job characteristics had a significant direct effect on organizational commitment. In addition, the results of the study also showed that employability and job characteristics had a significant indirect effect on contextual performance by mediating organizational commitment, each with path coefficient $=.015^{* *}$ and $.005^{* *}$ and $\mathrm{t}$ value $=2.79$ and 2.63. In figure 1 , the accuracy index of $\mathrm{p}$-value $=1.00000>.05$ and RMSEA $=.000<.01$, so that the model tested is fit. That means the theoretical model being tested is supported by empirical data.

\section{Discussion}

\subsection{Direct effect employability on contextual performance}

The results of this study have proven that employability had a positive and significant direct effect on contextual performance. The finding shows that employability was an important antecedent for contextual performance. Employability is an individual's capability in maintaining and developing competencies and qualifications that can increase his labor market participation on an ongoing basis or his career potential manifested in specific work skills, proactive, adaptability and balance to maintain organizational and personal interests. When these indicators are in good condition then it can stimulate the principal to show behavior that contributes to the effectiveness of school organizations by providing a good environment where all tasks can be carried out properly and optimally. The results of previous studies conducted by Abas-Mastura, Imam and Osman (2013), Philippaers et al. (2016), and Pinto and Ramalheira (2017) also show that employability affects contextual performance. Thus, these findings are consistent, support and confirm the results of previous studies that employability has a positive and significant direct effect on contextual performance with the setting of the principals of Private Vocational High Schools in DKI Jakarta Province, Indonesia.

\subsection{Direct effect job characteristics on contextual performance}

The results of this study also have indicated that job characteristics had a positive and significant direct effect on contextual performance. This findings have shown that job characteristics can be relied upon to increase contextual performance. Job characteristics is a collection of task attributes that exist in a job such as in the form of skill variations, task identity, task significance, autonomy, and feedback. These attributes if the conditions are in line with the expectations of the principal will provide encouragement for increase contextual performance. Job characteristics such as feedback will give enthusiasm to the principal in work, because everyone in work wants feedback as an evaluation material for their performance. Feedback such as in the form of appreciation or praise from the organization or leader shows the attention and recognition of the existence of the principal in an organization. This recognition will encourage principals to be more enthusiastic in realizing school goals. The results of previous studies conducted Johari et al. (2015), Brooks and Califf (2016), Rijanti, Priyono and Nugroho (2017), Amahwa and Mukanzi (2018), Abasalizadeh and Dadgarinezhad (2018); Sugianto, Muhyi and Purnomo (2018), and Peiroa et al. (2020) also showed that job characteristics influence contextual performance. Thus, these findings are consistent, support and confirm the results of previous studies that job characteristics has a positive and significant direct effect on contextual performance with the setting of the principals of Private Vocational High Schools in DKI Jakarta Province, Indonesia.

\subsection{Direct effect organizational commitment on contextual performance}

The results of this study also have shown that organizational commitment had a positive and significant direct effect on contextual performance. This finding shows vitality organizational commitment for contextual performance. Organizational commitment is a sense of identification, participation and involvement in the organization manifested in form: normative, continuance and affective commitment. When the principal can identify, participate and be involved normatively, continuously and affectively in the school organization, it can stimulate the principal to show behavior that contributes to the effectiveness of school organizations by providing a good environment where all tasks can be carried out properly and optimally. The results of previous studies conducted by Harwiki (2016), Anggapradja and Wijaya (2017), Renyut et al. (2017), Destari, Lumbanraja and Absah (2018), Khunsoonthornkit and Panjakajornsak (2018), Fajrin, Saragih and Indratjahjo (2018), Lin and Shiqian (2018), Metin and Asli (2018), Suharto, Suyanto and Hendri (2019) also show that organizational commitment influences contextual performance. Thus, these findings are consistent, support and confirm the results of previous studies that organizational commitment has a positive and significant direct effect on contextual performance with the setting of the principals of Private Vocational High Schools in DKI Jakarta Province, Indonesia.

\subsection{Direct effect employability on organizational commitment}

The results of this study also found that employability had a positive and significant direct effect on organizational commitment. This finding shows that employability is needed to develop organizational commitment. Employability is an individual's capability in maintaining and developing competencies and qualifications that can increase his labor market participation on an ongoing basis or his career potential manifested in specific work skills, proactive, adaptability and balance to maintain organizational and personal interests. When the indicators are in good condition, it can encourage the school principal to show 
optimal participation and involvement to achieve the school's goals. The results of previous studies conducted by Benson (2006), de Cuyper and de Witte (2011), and Yousaf and Sanders (2012) also show that employability affects organizational commitment. Therefore, these findings are consistent, support and confirm the results of previous studies that employability has a positive and significant direct effect on organizational commitment with the setting of the principals of Private Vocational High Schools in DKI Jakarta Province, Indonesia.

\subsection{Direct effect job characteristics on organizational commitment}

The results of this study also revealed that job characteristics had a positive and significant direct effect on organizational commitment. The finding shows that job characteristics can be used to build organizational commitment. Job characteristics is a collection of task attributes that exist in a job such as in the form of skill variations, task identity, task significance, autonomy, and feedback. Autonomy for example will give enthusiasm to the principal in work, because principals in work wants the freedom to complete their work. Autonomy is a job characteristic that gives certain principals a certain control and control in making work-related decisions. This dimension is fundamental to create a sense of responsibility within the principal. With this sense of responsibility, the principal will make every effort to complete their work as well as possible. Another form of job characteristic that has the potential to cause organizational commitment is the significance of the task. If the principal feels that what he has done has benefited others, himself or his family, it will further encourage his enthusiasm to complete each of his work and will lead to a stronger commitment in carrying out each task. The results of previous studies conducted by Chang and Lee (2006), Ali (2015), Obi-Nwosu, Chiamaka and Tochukwu (2013), Sabella, El-Far and Eid (2016) also showed that job characteristics influence organizational commitment. Thus, these findings are consistent, support and confirm the results of previous studies that job characteristics has a positive and significant direct effect on organizational commitment with the setting of the principals of Private Vocational High Schools in DKI Jakarta Province, Indonesia.

In addition, the results of the study also have shown that employability and job characteristics had a significant indirect effect on contextual performance by mediating organizational commitment. Thus, organizational commitment has a vital role in mediating the effect of employability and job characteristics on contextual performance. This also means that the model of the effect of employability and job characteristics on contextual performance with organizational commitment mediation can be utilized by researchers and practitioners in the future.

\section{Conclusion}

This research proves that employability, job characteristics, and organizational commitment have direct effects on contextual performance; employability and job characteristics have a direct effect on organizational commitment; employability and job characteristics have indirect effects on contextual performance by mediating organizational commitment. Therefore, a fit research model has been accomplished about the effect of employability and job characteristics on contextual performance by mediating organizational commitment. This model can be used as a reference by researchers and practitioners in developing models of contextual performance.

\section{References}

Abasalizadeh, Y., \& Dadgarinezhad, A. (2018). Investigating the effect of job characteristics on job involvement and job performance. Science Arena Publications International journal of Business Management, 3(4), 28-36.

Abas-Mastura, M., Imam, O.A., \& Osman, S. (2013). Employability skills and task performance of employees in government sector. International Journal of Humanities and Social Science, 3(4), 150-162.

Aguinis, H. (2013). Performance management. New Jersey: Pearson Education, Inc.

Ali, F. (2015). The effect of job characteristics on managers' intent to leave the organization: the mediating role of the four dimensions of organizational commitment. International Journal of Business and Management, 10(6), 239-250.

Amahwa, O. M \& Mukanzi, C.M. (2018). Eeffect of job characteristics on teacher performance in public primary schools in Kakamega East Sub county. The Strategic Journal of Business \& Change Management, 5(4), 1797-1807.

Anggapradja, I.T., \& Wijaya, R. (2017). Effect of commitment organization, organizational culture, and motivation to performance of employees. Jurnal of Applied Management (JAM), 15(1), 74-80.

Beardwell, J., \& Thompson, A. (2017). Human resource management: a contemporary approach, eighth edition. United Kingdom: Pearson Education Limited.

Benson, G. S. (2006). Employee development, commitment and intention to turnover: a test of 'employability'policies in action. Human Resource Management Journal, 16(2), 173-192.

Bernardin, H. J., \& Russell, J.E.A. (2013). Human resource management: an experiental approach, sixth edition. New York: McGraw-Hill Education.

Berntson, E., Sverke, M., \& Marklund, S. (2006). Predicting perceived employability human capital or labour market opportunities. Economic and Industrial Democracy, 27, 223-244.

Brooks, S., \& Califf, C. (2016). Social media-induced technostress: its impact on the job performance of it professionals and the moderating role of job characteristics. Computer Networks, 114, 143-153.

Byars, L.L., Rue, L.W., \& Ibrahim, N.A. (2016). Human resource management, $11^{\text {th }}$ ed., New York: McGraw-Hill Education.

Chang, S.C., \& Lee, M.S. (2006). Relationships among personality traits, job characteristics, and organizational commitment. The Business Review, Cambridge, 6(1), 201-207. 
De Cuyper, N., \& de Witte, H. (2011). The management paradox: Self-rated employability and organizational commitment and performance. Personnel Review, 40(2), 152-172.

Destari, Y., Lumbanraja, P., \& Absah, Y. (2018). The influence of work satisfaction on employees performance with organizational commitment as intervening variable at the mining and energy agency of north Sumatera. International Journal of Research \& Review, 5(12), 355-364.

Fajrin, D., Saragih, B., \& Indratjahjo, H. (2018). The effect of organizational commitment and organizational culture to employee performance through behaviour civilization organizations of teachers and employees madrasah Ibtidaiya Nurussyifa Indonesia. International Journal of Business and Applied Social Science (IJBASS), 4(3), 24-39.

Forrier, A., \& Sels, L. (2003). The concept employability: a complex mosaic. International Journal of Human Resources Development and Management, 3, 102-24.

Fugate, M., Kinicki, A. J., \& Ashforth, B. E. (2004). Employability: A psycho-social construct, its dimensions, and applications. Journal of Vocational Behavior, 65, 14-38.

Gibson, J. L., Ivancevich, J. M., \& Donelly, J. H. (2009). Organizations: behavior, structure, processes. Boston: McGraw-Hill.

Harwiki, W. (2016). The impact of servant leadership on organizational culture, organizational commitment, organizational citizenship behavior (OCB) and employee performance in women cooperatives. Journal Elsevier Procedia-Social and Behavioral Sciences, 219, 283-290.

Jackson, S. E., Schuler, R.S., \& Werner, S. (2009). Managing human resources. $10^{\text {th }}$ ed. Mason, USA: South-Western.

Johari, J., Yean, T.F., Yahya, K.K., \& Adnan, Z. (2015). Elevating job performance through job characteristics and work involvement. International Academic Research Journal of Social Science, 1(2), 69-82.

Khunsoonthornkit, A., \& Panjakajornsak, V. (2018). Structural equation model to assess the impact of learning organization and commitment on the performance of research organizations. Kasetsart Journal of Social Sciences, 39, 457-462.

Krejcie, R.V., \& Morgan, D.W. (1970). Determining sample size for research activities. Educational and Psychological Measurement, 30, 607-610.

Lin, L., \& Shiqian, W. (2018). The mediating effect of organizational commitment on leadership type and job performance. Journal of World Economic Research, 7(1), 14-20.

Metin, K., \& Asli, K. (2018). The relationship between organizational commitment and work performance: A case of industrial enterprises. Journal of Economic and Social Development (JESD), 5(1), 46-50.

Nauta, A., van Vianen, A., van der Heijden, B., van Dam, K., \& Willemsen, M. (2009). Understanding the factors that promote employability orientation: The impact of employability culture, career satisfaction, and role breadth self-efficacy. Journal of Occupational and Organizational Psychology, 82, 233-251.

Noe, R.A., Hollenbeck, J.R., Gerhart, B., \& Wright, P.M. (2015). Human resource management; gaining a competitive advantage. $9^{\text {th }}$ edition. New York: McGraw-Hill Education.

Obi-Nwosu, H., Chiamaka O, J.A., \& Tochukwu M, O. (2013). Job characteristics as predictors of organizational commitment among private sector workers in Anambra State, Nigeria. International Journal of Asian Social Science, 3(2), $482-491$.

Pan, Y. J., \& Lee, L.S. (2011). Academic performance and perceived employability of graduate students in business and management - An analysis of nationwide graduate destination survey. Journal Elsevier Procedia-Social and Behavioral Sciences, $25,91-103$.

Peiroa, J.M., Bayonab, J.A., Caballerc, A., \& Fabiod, A.D. (2020). Importance of work characteristics affects job performance: The mediating role of individual dispositions on the work design-performance relationships. Journal Elsevier Personality and Individual Differences, 157, 1-11.

Philippaers, K., de Cuyper, N., Forrier, A., Elst, T.V., \& de Witte, H. (2016). Perceived employability in relation to job performance: A crosslagged study accounting for a negative path via reduced commitment. Scandinavian Journal of Work and Organizational Psychology, 1(1), 1-15,

Pinto, L.H., \& Ramalheira, D.C. (2017). Perceived employability of business graduates: the effect of academic performance and extracurricular activities. Journal of Vocational Behavior, 99, 165-178.

Renyut, B.C., Modding, H.B., Bima, J., \& Sukmawati, S. (2017). The effect of organizational commitment, competence on job satisfaction and employees performance in Maluku governor's office. IOSR Journal of Business and Management (IOSR-JBM), $19(11), 18-29$.

Rijanti, T., Priyono, B.S., \& Nugroho, H.P. (2017). The influence of competence and job characteristics on performance with motivation as mediating variable at regional finance agency of tegal city. The Sixth International Conference on Entrepreneurship and Business Management (ICEBM), 16(17), 412-419.

Sabella, A.R., El-Far, M.T., \& Eid, N. L. (2016). The effects of organizational and job characteristics on employees' organizational commitment in arts-and-culture organizations. International Journal of Organizational Analysis, 24(5), $1002-1024$.

Sugianto, H., Muhyi, H.A., \& Purnomo, M. (2018). The effect of job characteristics on job satisfaction and its impact on employee performance. Advances in Social Sciences Research Journal, 5(9), 95-101.

Suharto, S., \& Hendri, N. (2019). The impact of organizational commitment on job performance. International Journal of Economics and Business Administration, 7(2), 189-206.

Van der Heijde, C.M., \& van der Heijden, B.I.J.M. (2006). A competence-based and multidimensional operationalization and measurement of employability. Human Resource Management, 45(3), 449-476.

Yousaf, A., \& Sanders, K. (2012). The role of job satisfaction and self-efficacy as mediating mechanisms in the employability and affective organizational commitment relationship: a case from a Pakistani university. Thunderbird International Business Review COMSATS Institute of Information Technology, 54(6), 907-919.

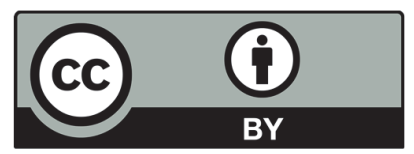

(C) 2020 by the authors; licensee Growing Science, Canada. This is an open access article distributed under the terms and conditions of the Creative Commons Attribution (CC-BY) license (http://creativecommons.org/licenses/by/4.0/). 